\title{
In Search of Hidden Histories, Agency and Global Network: A Response to the Articles on Women and Christianity in East Asia
}

\author{
Hyaeweol Choi \\ Associate Professor of Korean Studies \\ Arizona State University \\ hchoi@asu.edu
}

The three articles included in this volume engage a number of key questions related to women's experiences in the history of Christianity in East Asia. In particular, they explore the following questions in one way or another: For East Asian women whose lives have been deeply shaped by Confucian gender ideology, what does it mean to become Christian; How has the imported religion interacted with existing religious traditions and local cultures?; What ramifications has the adoption of the new religion had for women in terms of advancing their status in society and the church? How have Christian women coped with the tensions between church and state? What structural and discursive forces have shaped women's experiences in Christian spirituality and church organizations? In what ways have women found agency in choosing their own life path?

Each of the articles focuses on a different set of historical circumstances in bringing forth key arguments about the Christian experience of women in East Asia. Haruko Nawata Ward's piece excavates the hidden history of women who devoted their lives to the new religion and ultimately became martyrs during the Tokugawa period (1603-1868) in Japan. She teases out the ways in which newly converted women waded through the persecution with particular strategies and networks. Kwok Pui-lan's article elucidates the complex and intimate relationship between religion and politics embedded in particular historical circumstances in China and Hong Kong. Kwok analyzes how Christian women use hermeneutic theological interpretations and various other activities in their attempts both to negotiate with and resist the patriarchal church organizations. Proposing the notion of religious choice-in-differential, Namsoon Kang's article points to the problems of religious similarities in ecumenical methodology and specifically 
criticizes previous studies that attempt to find similarities between Confucianism and Christianity. She argues that women accepted Christianity because it offered "a transformative and liberative space and practice for the marginalized" in the early history of Christianity; however, over the years "Confucianized Christianity" lost its liberating character.

One of the key threads that tie these articles together is the idea that the religious encounters are examples of "transnational" encounters within a specific political, economic and cultural context. I am using the term "transnational" to refer to the dynamic flow of ideas, people, images, norms and material cultures across national borders. The flow is shaped not only by the broader global political economy in the form of colonialism and war, but also by the will of individuals who seek an alternative space for freedom and autonomy within the constraints of contemporaneous circumstances. Religion has been one of the most critical factors shaping these transnational interactions in which people of disparate cultural and historical background engage in propagating, resisting or appropriating a newly introduced religion. In this vein, the history of Christianity in East Asia and women's conversion experiences shed light on the ways in which the newly introduced religion was accepted, resisted or reinterpreted through its contact with the local cultures, politics and people.

Recognizing the ways in which a new religion makes inroads into communities with long-established indigenous religious traditions is crucial for our understanding of religious encounters. It has been repeatedly demonstrated that there is always some level of creative adaptation and cultural negotiation. For example, Ward shows that the original Christian literature was creatively adapted to the Japanese context by using Buddhist terms in order to explain new Christian ideas. In Kwok's analysis, Chinese feminine virtues, such as submissiveness, meekness, and humility, find a similar tone and emphasis in Christian teachings. While finding similarities has always been an important strategy, as Kang's article stresses, it is equally significant to find what "differences" exist and the impact that the differences have on the conversion experience. This dynamic tension between continuity and discontinuity and between connection and disconnection need to be more fully fleshed out to understand how old and new religions are comprehended, negotiated and appropriated. Paying attention to these tensions will also help us analyze the extent to which a newly introduced religion has been localized and hybridized and, in some cases, transformed into a different new religion. 
We turn our attention to the specific claims of each of the articles. Haruko Nawata Ward takes up the very challenging task of excavating the history of women martyrs in the pre-modern era. Much literature about them was destroyed during Tokugawa-era persecution, and Ward's article specifically focuses on two sources of text. One is "Kirishitan edition martyrologies, which the Jesuits produced in collaboration with the Kirishitans." These were written in kanamajiri script specifically for women, who had relatively high literacy at the time in comparison with their counterparts in Europe. The other source is "Jesuit missionary letters, which preserved women's words and described their actions." Given the scarcity of literature about these women martyrs, the fact that Ward has brought theses sources forward is invaluable; however, it is important to keep in mind that they are the product of the Jesuit missionaries and therefore necessarily limited to their perception and experience. In order to cope with the challenges stemming from sheer lack of direct voices of women martyrs themselves, we must approach archival documents in a more creative way. That is, we should not only look at what has been selected and recorded, but also ask what is missing; what are the implications of the absence of certain information; and what kind of religious and secular interests might have shaped the politics of the archive. These questions may help us think beyond the constraints of archival preservation.

Despite the lack of direct data for understanding the lives of women converts, Ward's article still offers insight into those women who travelled, often times by force, to remote areas or foreign countries and became martyrs. For example, Korean women who were brought to Japan as hostages during the Toyotomi Hideyoshi invasion of Korea (1592-1598) became Christian and eventually martyrs. Ward also highlights how these Christian women who shared the same religious devotion and underwent persecution together had an alliance that cut across the lines of race, class, ethnicity and national origins. The story of Naitō Julia and Paccu Marina, a Korean native, who were sent to Manila in 1614 as part of a program of religious persecution, is a poignant episode that illustrates spiritual bond that existed among converts from different ethnic groups. It would be fascinating to know what happened in the lives of Christian women in the Philippines during the Spanish colonial period when the Spanish tried to convert the local people to Catholicism, how it was possible to send these Japanese/Korean women to Manila, and what political ties were there between the Tokugawa power and the Spanish rule in the Philippines. I think that transnational research can be fruitfully conducted by examining the local and 
transnational connections in the experience of these women who were exiled to other countries.

One of the most interesting findings about women martyrs in Japan is that they were well versed in knowledge of theological issues, and perhaps more importantly, they were not isolated but worked in the network of communities of women. The existence of a network of women's communities is crucial to understanding not only the conversion process but the preservation and proliferation of the faith. Ward pays special attention to women's use of the "espoused Christian monastic virginity as the supreme virtue" and "as a weapon of resistance." Ward notes that Japanese Christian women in exile in the Philippines "refused marriage for political and religious alliance, arranged by their families and village officials, and used their vows of virgindade [virginity] as a weapon of resistance." Their resistance here can be understood as a coping strategy not only under religious persecution but also patriarchal oppression. I think that this strategy has a significant resonance with the Victorian notion that women's purity and chastity made them morally superior to men's loose morality, and that superiority should allow women to assert their own power and authority within the domestic arena. ${ }^{1}$ A recent study on Korean Buddhist nuns during the Chosŏn dynasty (1392-1910) in Korea also reveals that women fled to temples and remained celibate to avoid patriarchal oppression at home. ${ }^{2}$ What can be drawn from these women's experiences across cultures is that their choice of virginity and chastity was far from an act of compliance; rather, it was a proactive gesture to claim power for themselves and control over their own bodies.

Kwok Pui-lan's article illustrates one of the key questions about tensions between church and state and between foreign/western mission and indigenous/national mandates within the context of turbulent political history of China. The founding of the People's Republic of China (PRC) in 1949 was a transitional moment in the history of Christianity in China. It led to the labeling of the foreign mission as part of cultural imperialism and promoting patriotism/nationalism within the socialist system. The Cultural Revolution (1966-1976) resulted in all churches being shut down; only after China adopted an open-door policy

1 Nancy Cott, The Bonds of Womanhood: "Woman's Sphere" in New England, 1780-1835 (New Haven: Yale University Press, 1977).

2 Ji Young Jung, "Alternative Space for Buddhist Nuns in the Confucian Chosŏn Dynasty," a paper presented at the International Symposium, "Invoking Gender in Korean Religious Traditions," held at Arizona State University, November 16-17, 2006. 
beginning in1976, did Christian churches begin to reopen, and since then the church has been experiencing unprecedented rapid growth.

A unique characteristic of Chinese women is that their conversion to Christianity cannot be separated from the above-mentioned political turmoil and begs an important question about the relationship between Chinese Christian feminism and Confucian and Communist gender ideologies. Kwok notes that Chinese Christian women's feminist consciousness reached a high point during the May Fourth movement. To be sure, feminist consciousness was an integral part of the spirit that fashioned the May Fourth Era (1915-1924) along with the antiimperialist, communist, and nationalist movements. What is not clear is the relationship that existed between Christianity and all of these social movements. Given the close ties between Chinese Christians and foreign missionaries, how did Christian women in the May Fourth movement cope with or reconcile with the foreign origin of the Christian mission within the prevailing anti-imperial orientation among intellectuals? In addition, the Communist Party of China (founded in 1921) was deeply influenced by feminism and "shared a set of expectations about the importance of women's equality in developing a new political and social order."3 Again, a question can be posed about the relationship between Christian feminists and the Communist party, which has a longstanding policy toward gender equality, at least at the ideological level, and has an anti-imperial orientation coupled with a strong nationalist mandate. Kwok points out that "the socialist revolution has not succeeded in female liberation and that old patriarchal values still existed in the church." This was precisely the reason why a schism developed between traditional Christians, who held on to rather traditional gender norms, and the adherents who were shaped by the Cultural Revolution's notion of gender equality. It will be an important area of research to examine the various factors playing out within the church that still perpetuate patriarchal gender practices, even after the enforcement of communist policies on gender equality.

Under the strong governance of the socialist regime, finding a delicate balance and comparability between communism and Christianity is an imminent task for Chinese Christian women. As Kwok notes, the strong atheistic stance of the Community regime is the backdrop of the contemporary history of Christianity in the PRC. In this vein, some leading Christian women have tried to find a strategic alliance between

3 Christina Kelley Gilmartin, “Introduction: May Fourth and Women’s Emancipation," in Women in Republican China: A Sourcebook, eds., Hua R. Lan and Vanessa L. Fong (New York: M. E. Sharpe, 1999), xx. 
Christianity and Communism with heavy focus on patriotism and Chinese contexts, recognizing the contribution of the Communist policies to the abolition of old practices, such as prostitution, opiumsmoking and gambling. Our enhanced understanding of the unique context of the PRC will shed new light on the continuing tensions between Christianity and Communism and between church and state.

Given the disparate historical experiences between mainland China and Hong Kong, I am wondering how the women from China and Hong Kong manage to collaborate? Are there conflicts in their theological interpretations, feminist practices in the church, relations with the political authorities and others? It would be very useful to know some of the key points of agreement or disagreement among feminist theologians who have attended or will attend conferences, such as the one mentioned in Kwok's article, "Feminist Theology in Chinese Contexts."

Namsoon Kang raises an important question in her article: "why women in a non-Christian world turn away from their traditional "indigenous" religions and move to Christianity as an alternative religion." She argues that "when one makes a religious choice for a "foreign" religion such as Christianity, one bases the choice on the difference from, not the similarity with, the existing "indigenous" religions." A set of questions can be raised here. For any distinctive differences, how do people understand the "differences" and in what ways the "differences" are represented and possibly appropriated by the local. I raise this question with particular attention to one common claim about gender equality promoted by Christianity. I think that the literal acceptance of the notion of equality under God often overlooks the institutional and discursive mechanisms that deny such equality in reality. What is envisioned in Christian doctrines needs to be understood in relation to whether such a noble vision is practiced in reality. The fact that Elizabeth Cady Stanton and her colleagues published a book, entitled The Woman's Bible (1895), in which they critiqued culturally constructed, male-centered biblical interpretation. They argued that clergymen believed that women "owed all the blessings and freedom they enjoyed to the Bible" but at the same time that "the demands for political and civil rights were irreligious, dangerous to the stability of the home, the state and the church." Thus the church took the paradoxical position that women were endowed with their freedoms by the Bible, but that demands for freedom were antithetical to the Bible. Focusing on this contradiction, Stanton and her co-authors put a straightforward question to men: "If the Bible teaches the equality of Woman, why does the 
church refuse to ordain women to preach the gospel, to fill the offices of deacons and elders, and to administer the Sacraments, or to admit them as delegates to the Synods, General Assemblies and Conferences of the different denominations?" They further critique men's attempt to ostracize women who were demanding political and civil rights because they were adversative to Christian feminine virtue. ${ }^{4}$

In a similar but reverse fashion, "Confucianism" is often condemned as the epitome of patriarchal oppression. To be sure, it is a male-centered ideology with numerous examples of discriminatory gender practices. Yet, Confucian history in Korea, and for that matter in other Asian countries, is complex. Confucianism was actively introduced to Korea from the Three Kingdom Period (57 BC-668). Through the use of Confucian texts, educational institutions inculcated Confucian values that became the basis for political and ethical cohesion. However, Confucianism's impact on women came to be felt most profoundly with the founding of the Chosŏn dynasty in 1392. During the Chosŏn dynasty Confucianism was not a unitary system that pervaded throughout the history of the period. It took a few centuries for the new dynasty to institutionalize Confucianism, and it is only from the $17^{\text {th }}$ century that the impact of Confucian arrangements began to have a pervasive impact on people and institutions. Before what Martina Deuchlar called the "Confucian transformation" 5 in Korea, women enjoyed freedom and some level of equality. The understanding of this changing role and status of women from fairly equal to increasingly unequal gender relations over time is a key to our understanding of gender and Confucianism within specific historical contexts.

Even during the period when Confucian ethics and institutions were fully implemented, portraying women as completely marginal and powerless does not do justice to the reality of women's lives. While one of the Five Human Relations dictates the "distinction between men and women," that does not necessarily mean women's role was minimal. Indeed, the "inside" or domestic affairs were highly valued, and women took full responsibility in maintaining and supporting family tradition. Further, women confined to the domestic arena still had an impact on the

4 Hyaeweol Choi, Gender and Mission Encounters in Korea: New Women, Old Ways (Berkeley: University of California Press, 2009), 25-26. 
public sphere through their exercise of moral virtue. ${ }^{6}$ An increasing number of research studies demonstrate that women under Confucian doctrines were not necessarily deprived of all rights and freedom. For example, in contradiction to the common belief, women did have ties with their native families even after marriage, and some women held the title of head of the household. ${ }^{7}$ Within limits, these women found ways to exercise their power and authority. The type of autonomous space that Korean women enjoyed can be similarly found in other cultures and societies that were also governed by patriarchal norms.

Kang observes a "shift of Christianity in Korea from a liberative to a patriarchal religion in which people "naturalize" women's marginality in theology and ministry as the Divine order in the guise of false egalitarianism of "equal but different." She explains that the "naturalizing" process was aided by discursive and institutional arrangements. It would be equally important to explore the role of women in that process. Have women been passive or resistant to that process? Or have women been complicit with it? As Kelly Chong's research on contemporary South Korean women in Protestant churches demonstrates, church women have greatly contributed to the conservative and patriarchal church organizations and relations, while they still find ways to empower themselves by following and conforming. ${ }^{8}$ In this vein, a more detailed and concrete example would be helpful for illustrating the duality in which women are the victims of patriarchal powers, while they nevertheless engage in these very patriarchal structures in order to exercise their own autonomy and empowerment.

As a way to conclude, I would like to raise a couple of topics for future research studies.

6 John Duncan, "The Naehun and the Politics of Gender," in Creative Women of Korea: The Fifteenth through the Twentieth Centuries, ed. Young-Key Kim-Renaud (Armonk: M. E. Sharpe, 2004), 26 - 57; Martina Deuchler, "Propagating Female Virtues in Chosǒn Korea," in Women and Confucian Cultures in Premodern China, Korea and Japan, ed. Dorothy Ko, JaHyun Kim Haboush and Joan Piggott (Berkeley and Los Angeles: University of California Press, 2003), 142 - 69; Yi Sug-in, "Yugyo ŭi kwan'gye yulli e taehan yŏsŏngjuŭi chŏk haesŏk" (Feminist Interpretations of Relational Ethics in Confucianism), Han'guk yǒsŏnghak 15, no. 1 (1999): 39 - 69.

7 Jung Ji Young, “Chosŏn hugi ŭi hojŏk kwa yŏsŏng hoju” (The Family Registry System and Women Head of the Household in Late Chosŏn), Yǒsŏng kwa sahoe 14 (2002): 142-57.

8 Kelly Chong, Deliverance and Submission: Evangelical Women and the Negotiation of Patriarchy in South Korea (Cambridge: Harvard University Press, 2008). 
One important area for future research is to understand the variation within Confucianism. How did local Confucianisms throughout East Asia shape the religious experience of Christian women in both similar ways and differently. It is important to recognize pluralities in religious conversions and experiences as people intersected with disparate traditions, cultures, languages, and materiality. While some central tenets of Confucianism might be shared, its historical development vividly reflects local, particular histories. Keeping this in mind, excavating the complex histories of the lives and experiences of Christian women within the local patriarchal systems of Confucianism and comparing those local histories with each other will shed new light on the interplay between the indigenous and the foreign and between the oppressive patriarchal arrangements and women's agency in shaping their religious and secular lives.

Another area for further investigation is the impact of globalization on feminist theology and the women's movement at the grassroots level. Postcolonial theories and perspectives have helped us understand the epistemological, cultural and sociopolitical roots embedded in the ways we understand and think about religion, gender relations and the world. Just as western-centered feminism has been scrutinized by feminists from the Third World, so should feminist theology be an important subject of analysis by paying close attention to the transnational flow of discourse and theories. Kwok Pui-lan refers to a conference called "Feminist Theology in Chinese Contexts." This type of intellectual inquiry will be of great help in identifying both unique and shared realities that East Asian Christian women face in their spiritual lives.

The sheer pace and intensity of globalization in the past few decades has been unprecedented. This trend has literally affected all sectors. What would be the ramifications of the changing status of East Asia in the world economy, politics and culture for Christian women and their role in society, the family and the global community? Feminist historian Judith Bennett has suggested that one strategy for bringing about a better understanding of the mechanisms of persistent patriarchy is to undertake case studies incorporating specific historical contexts, especially times of exceptional crisis, and to examine how historical "transitions challenged patriarchies, how patriarchies changed in response to these challenges, and how patriarchies nevertheless 
endured." 9 The era we are living in might be one of those critical ruptures in history that embeds major challenges to the status quo in terms of gender relations and heralds new visions and practices for $21^{\text {st }}$ century womanhood.

9 Judith M. Bennett, "Feminism and History," Gender \& History 1, no. 3 (Autumn

1989): 259. 